\title{
Reconceptualization of Local Wisdom through Kelong Makassar: A Semiotic Review of Michael Riffaterre
}

\author{
Hajrah \\ Universitas Negeri Makassar, K . Bonto Langkasa, Kampus Gunung Sari, Makassar, South Sulawesi, Indonesia \\ Rapi Tang \\ Universitas Negeri Makassar, K . Bonto Langkasa, Kampus Gunung Sari, Makassar, South Sulawesi, Indonesia \\ Suradi Tahmir \\ Universitas Negeri Makassar, K . Bonto Langkasa, Kampus Gunung Sari, Makassar, South Sulawesi, Indonesia \\ Kembog Daeng \\ Universitas Negeri Makassar, K . Bonto Langkasa, Kampus Gunung Sari, Makassar, South Sulawesi, Indonesia
}

\begin{abstract}
This study employs a qualitative descriptive research design. The data in this study are words in the lines and stanzas of Kelong Makassar containing the concept of Makassar local wisdom. The techniques of data collection users are reading, observation and document study. The data analysis technique used in this study is the interactive model of data analysis developed by Miles and Huberman (1992). The data analysis includes data collection, data reduction, data display and conclusion drawing/verification. The data were analyzed to obtain the concept of local wisdom through the meaning of Kelong Makassar. The results of this study reveal the meaning of Kelong based on the review of Michael Riffaterre's indirection of meaning and show that (1) displacement of meaning in this analysis was found through figurative language in the form of metaphor, metonymy, pars pro toto and personification, (2) distortion of meaning was found through ambiguity and contradiction, (3) creation of meaning was found through enjambment and typography.
\end{abstract}

Index Terms - reconceptualization, local wisdom, kelong, indirection of meaning

\section{INTRODUCTION}

Local wisdom is the reflection of cultural constellations and is a very complex concept of civilization; serving as a sign in every aspect of life. Therefore, each tribe in Indonesia makes local wisdom as their cultural richness that must be preserved. Nasaruddin et al. (2011, p.11) argue that local wisdom is often conceptualized as local knowledge and local genius used as a view of life, science and various activities carried out by local communities in overcoming problems regarding life needs which are also increasingly complex.

Research relevant to this study was conducted by Razi Bezar et al. (2016) entitled Semiotic Analysis of Place and Time in Poems of Badr Shakir al-Sayyab. This article was published in the Journal of History Culture and Art Research Vol. 5, No 4, December 2016. This study analyzed Sayyab's poetry using a descriptive, analytical method. This research analyzed spatial cues that help find the beauty of Sayyab's poetry and its hidden treasures of intellectual knowledge. Furthermore, relevant research was also carried out by Lerri alfayanti et al. entitled Symbolic Meanings of Among Tebal Ritual in Novel Genduk By Sundari Mardjuki. This research illustrates the symbolic meaning of the among ritual, namely the symbolic meaning of ritual offerings consisting of white, yellow, red, and black tumpeng (cone-shaped dish), symbolizing the four elements in human beings. This research also describes the way of life of the tobacco farmers of the slopes of Mount Sindoro reflected in the among ritual.

A related study was also conducted by Aytekin entitled On the Tracks of Literary Structure in Literary Work (a Sumerian Poem). The results of this study include abstract literary interpretation and analysis of the structure of literary texts from real expressions. This research is in line with Globe's research (1974) entitled The Literary Structure and Unity of the Song of Deborah, which discusses the meaning of poetry in the Deborah song.

In contrast to the above studies, the current study attempts to investigate the meaning contained in the literary work of Kelong Makassar and efforts to maintain Kelong as a medium to preserve local wisdom, which is the basis of national character. Also, it is used as a medium for character education of the young generation, primarily based on local wisdom in South Sulawesi in general and Makassar in particular. The reason for this research is to reveal and develop in detail and comprehensively the reconceptualization of local wisdom in Makassar literature, especially in 
Kelong as one of the efforts to preserve local culture. Therefore, this study was conducted to reveal the meaning of Kelong Makassar as cultural wealth.

Another underlying reason for this research is that Kelong Makassar is one of the cultural expressions of the people of Makassar and South Sulawesi in general that need to be explored, maintained and preserved by means studying it. Also, Makassar literary works contain cultural values that can be used as a medium to develop children's character education as the nation's next generation. Thus, this study was conducted under the title Reconceptualization of Local Wisdom through Kelong Makassar: A Semiotic Review of Michael Riffaterre.

Michael Riffaterre (1984) in his book Semiotics of Poetry suggests that there are four things to be taken into consideration in understanding and interpreting a poem. Those include: (1) poetry is an indirect expression, expressing something with another meaning, (2) heuristic reading and hermeneutic (retroactive) reading, (3) matrix, model, and variance, and (4) program. One of the four concepts of Riffaterre used in this study to investigate the reconceptualization of local wisdom in Kelong is the concept of indirection of meaning given that Kelong is a unique form of oral literature the meaning of which cannot be understood directly without the help of approaches/theories.

Referring to the background above, the problem in this study was generally formulated as follows: how is the form of a reconceptualization of the meaning of local wisdom in Kelong Makassar based on Michael Riffaterre's semiotic approach? The problem can be specified as follows: (1) what is the meaning of Kelong in terms of displacement of meaning? (2) what is the meaning of Kelong in terms of distortion of meaning? (3) what is the meaning of Kelong in terms of creation of meaning?.

This research is expected to provide theoretical and practical significance. Theoretically, (1) this research is expected to be a reference for other researchers planning to develop the values of Kelong Makassar related to the application of character education in learning models at the expected level. (2) This research is expected to help educators foster the local character of their students through literacy learning of Makassar Kelong as one of the lessons in literary arts and culture subject and at the same time preserving the local wisdom as the ancestral heritage of Makassar people, which has gradually been eroded by modernization in all aspects of life. (3) This research is expected to contribute in terms of science to education, especially in the field of literature.

Practically, (1) this research is expected to provide information to all components of society as a connoisseur of literature about the need to maintain the values of local wisdom as an educational tool for the community, especially for children as the nation's next generation. (2) This study is expected to enrich the researchers' knowledge, primarily related to the application, utilization, development, and preservation of local wisdom as a guide to living in society.

\section{LITERATURE REVIEW}

\section{A. Local Wisdom}

In the context of anthropology, local wisdom means indigenous or local knowledge or local genius, which is the basis of cultural identity. According to Sibarani (2012), local wisdom is a conceptual idea that lives in society, grows and develops continuously in a society that regulates its life from the sacred to the profane. Local wisdom is the result of the adaptation of a community derived from life experiences communicated from generation to generation. Local wisdom is a local knowledge that is used by a community to survive in an environment that integrates with a system of beliefs, norms, culture and is expressed in the traditions and myths adapted for a long time. Local wisdom is a view of life, knowledge, as well as various life strategies in the form of activities, carried out by local communities in overcoming problems in meeting their needs.

\section{B. Literature}

\section{Definition of Sastra (Literature)}

The word of literature comes from Sanskrit (sastra), a loanword, which means a text containing instructions or guidelines, from the word sas, which means instruction or teachings, and tra, which means tools or means. Literature is the result of creative activities or artworks in the form of writings or texts that uses language as a medium to express or describe life, humanity, or reality.

2. Oral Literature

Oral literature is part of folklore in the literary genre (Suwardi, 2009, p.17). This is by the main characteristics of folklore such as (a) its dissemination and inheritance as a literary work build the world through words because words have energy. It is through this energy that the image of a particular world is formed as a new thing. Those words also have documentary aspects that can penetrate space and time beyond the capabilities of other aspects of culture. Makassar's oral literary works still exist in the midst of people's lives, although many are not well developed. However, there are still many efforts made by various parties to preserve, maintain and develop Makassar oral literature, as in the form of research with diverse objectives.

3. Makassar Literature

Makassar literature is all the art products born creatively with enthusiasm and written in the Makassar language (Basang, 1975, p.3). According to Basang (1975, p.3), Makassar literature in the past was written in three types of letters, namely the ancient Makassar letters, Arabic letters, and the new Makassar letters. Makassar Literature can be deepened through oral literary works of the existing community. In terms of its form, Makassar literature consists of 
three types, namely poetry, prose, and rhythmical verse. Basang (1975, p.4) adds that Makassar literary works belonging to poetry are doangang, paruntuk kana, kelong, dondo, aru, rapang, and pakkiok bunting. Meanwhile, those belonging to prose are rupama, pau-pau, and patturioloang and those belonging to rhythmical verse are royong and sinrilik.

\section{Kelong}

Kelong is a type of Makassar literary work that has high value in terms of both content and form of expression because it has its characteristics different from other literary works. Kelong contains messages that can be used as learning materials for its connoisseurs. Hakim (1998, p.1) stated that Kelong is a type of poetry (Makassar pantun). Kelong is one of the most well-known and developing forms of literary work in the community, especially those with Makassar cultural background and those speaking Makassar language. Kelong is a type of Makassar literature in the form of poetry. Concerning its form, Kelong, especially traditional Kelong, has similarities with pantun in Indonesian literature, for example having four lines in one stanza, having rhyme, and having no title. Kelong is a type of Makassar poetry as Poetry can realise the life period of poets through signs of time and place. Signs and forms can also record internal formats, music, and lyrics, which are consistent with the content of poetry (Pashaki, 2016).

\section{Michael Riffaterre's Semiotics}

Semiotic cannot be separated from the term symbolic. Both of these terms tend to be used interchangeably, but Kristeva in Sadehi (2012) suggests that semiotic and symbolic references to two interdependent aspects of language. Semiotics is defined as the matriarchal aspect of language that shows the speaker's inner drives and impulses, while symbolic is the aspect of language governed by rules, which shows itself in grammar and syntactic structure.

The literary phenomenon is a dialectic between texts and readers. According to Riffaterre (1984, p.1), in a broader context of literature, poetry cannot be separated from the concept of text. If the poem is not considered a closed entity, we cannot always distinguish poetic discourse from the literary language. Riffatere's semiotic theory can be used in understanding the meaning and teachings of manners, which are one's particular character contained in poetry. (Setiawan et al., 2017)

The literary phenomena, however, is dialectic between text and reader if we are to formulate rules governing this dialectic, we shall have to know that what we are describing is perceived by the reader. We shall have to know whether he is always obliged to see what he sees, or if he retains individual freedom. Also, we shall have to know how perception takes place. Within the broader realm of literature it seems that poetry is peculiarly inseparable from the concept of text, if we do not regard the poem as a closed entity, we cannot always differentiate poetic discourse from the literary language.

Michael Riffaterre (1984) in his book Semiotics of Poetry suggests that there are four things to be taken into consideration in understanding and interpreting a poem. Those include: (1) poetry is an indirect expression, expressing something with another meaning, (2) heuristic reading and hermeneutic (retroactive) reading, (3) matrix, model, and variance, and (4) program ( Salam, 2009, p.3).

\section{RESEARCH METHOD}

\section{A. Type of Research}

This study is a qualitative study that leads to culture-oriented library research, based on cultural phenomena. The data was presented empirically. The empirical data in question is contained in the literary work of Kelong Makassar as a medium of the written presentation.

\section{B. Research Focus}

There are three main focuses of this study, namely first revealing the displacement of meaning in Kelong Makassar, second revealing the distortion of meaning in Kelong Makassar, and third revealing the creation of meaning in Kelong Makassar which is one form of local wisdom of the Makassar community.

\section{Definition of Terms}

The terms used in this study include: (1). Kelong literature is a form of Makassar literary work as poetry that uses the Makassar language as its medium. (2) Local wisdom refers to local ideas that are full of wisdom and embedded values and that are followed by local people. (3) Reconceptualization means conventionally rebuilding the pre-existing concept through understanding. (4) Semiotics is a theory that considers social phenomena (society) and culture assign. Semiotics also studies systems, rules, conventions that allow these signs to have meaning.

\section{Research Design}

By the paradigm used, the design of this study is a qualitative descriptive research design. This is based on the consideration that several methodological principles related to the presence of researchers, research location, data and data sources, the data collection procedure, research instruments, data analysis, and data validity are in line with the characteristics of qualitative research design. 


\section{E. Data and Source of Data}

The data in this study is in the form of Kelong Makassar containing meaning based on the local wisdom of the Makassar people. The meaning in question is determined in the forms and types of Kelong to be analyzed. Furthermore, the data were analyzed based on a semiotic theory with the concept of indirection of meaning.

\section{F. Techniques of Data Collection}

(1) Reading, The researchers collected Kelong Makassar scripts to be analyzed and then read them repeatedly and carefully. (2). Observation, The researchers collected information from trusted informants about the truth of the values contained in the literary works based on the character possessed by the Makassar community as the owner of the analyzed literary works.

\section{G. The Technique of Data Analysis}

Data analysis was performed during the data collection process and after the data was collected. The data analysis technique used in this study is the interactive model of data analysis developed by Miles and Huberman (1992). Miles and Huberman argued that activities in qualitative data analysis were carried out interactively and took place continuously until complete in order to reach data saturation.

\section{H. Research Instruments}

In this study, the researchers act as the main instrument. As the main instrument, the researchers surveyed to determine the literary works to be, and that contained the elements studied, namely the values in the literary work of Kelong Makassar. This study is a qualitative descriptive study that requires.

\section{Data Validity}

In the data analysis, there is a possibility of different interpretations. Thus triangulation and assessment of the results of data analysis from several experts, colleagues, and the analysis process through relevant theories are required so that the validity of the research findings can be accounted for. The experts in question are those who meet the requirements, have adequate knowledge and experience in the field of literature and culture of Makassar, academics who teach language, literature, and culture of Makassar, researchers, and practitioners in the field of language, literature, and culture of Makassar.

\section{RESULTS}

This study deals with three problems, namely the meaning of kelong based on the displacement of meaning, meaning of kelong based on a distortion of meaning, and meaning of kelong based on the creation of meaning. In this respect, Riffaterre argues that poetry is an indirect expression and those three things cause the indirection.

\section{A. Displacement of Meaning}

Displacement of meaning occurs when a sign changes from one meaning to another. Generally, figurative words replace the meaning of something with something else. In kelong Makassar, there is a displacement of meaning through figurative language in the form of metaphors, metonymy, pars pro toto and personification.

a). Metaphor

According to Sadehi and Abdullah (2015), metaphor, alliteration, and other poetic devices are part of the semiotic aspects of language. Diegnan in Ahmed stated that metaphor could be defined as a word or phrase used to talk about an entity or quality other than the meaning intended. The metaphor is found in the following kelong;

(1) Kuminasaiko sunggu

Kutinjakko matekne

Manna pucuknu

Tangkennu matekne ngaseng

The word matekne in the kelong above is a metaphorical word, which means sweet. This word gives a different meaning in terms of analogical comparison. Matekne, which means sweet, is a metaphor for happiness. Similarly, the word pucukna means the youngest shoot or leaf of a plant. If this word is related to the context of the sentence, this word gives a different analogical meaning. Pucukna is a metaphor for grandchildren. The word tangkenna, which means stalk, analogically means children. Therefore, Kelong means a prayer from someone who expects people he/she is praying for to get happiness for their families including their children and grandchildren. This is confirmed by the last line of this kelong, matekne ngaseng, which means all is sweet and is the metaphor for all is happy.

b). Metonymy

Metonimie is often called the substitution of a name. This is the use of an attribute of an object or the use of something very close and related to the object to replace the object (Pradopo, 2007, p.77). The Kelong text that contains metonymic change of meaning is found in the following data;

(2) Karaeng Alla Taala

Karaeng mappakjaria

Ia kusomba 
Ia tong kupaknganroi

In data (2), the word kupakknganroi means 'asking'. The word nipaknganroi is the metonymy of the word appalak, which also means 'asking' but in a different context. In this case, even though both have similar meaning, the context of using these words in a sentence is not always the same. Nipaknganroi is a polite word while appalak is a rude word.

c). Personification

Personification is a figure of speech where human qualities are given to objects or ideas. Inanimate objects are described as being able to act, think, and so on like humans. Poets from the past until now have widely used personification. Personification makes a description come alive, besides giving clarity and an accurate reflection. Personification is found in the following data.

(3) Battu ratemak ri bulang

Makkutaknang ri bintoeng

Apa kananna

Bunting lompo jako sallang

In data (3) above, personified expressions treat the moon and stars like living things that we can communicate with them; Battu ratema ri bulang 'I have been to the moon', makkutaknang ri bintoeng 'asking the stars'. Apa kananna 'what they said', bunting lompo jako sallang "you will have a big wedding party'. These expressions seem to imply that the questioner gets an answer from the stars. These expressions have deep meanings although they are personified as inanimate objects are considered as living things. Indeed, humans will always expect blessings from their Creator when they do or will do something.

d). Pars Pro Toto

Pars pro toto is a figure of speech where the name of a portion of an object, place, or concept represents its entirety. The expression containing pars pro toto is presented in data (4) below:

(4) Papisangkana ri katte

Pakabellai ri ati

Na nitunrai

Eroka makgauk sala

In data (4) above, the second line indicates pars pro toto. It reads Pakabellai ri ati 'keep it away from the heart'. The expression is a pars pro toto because the heart here refers to the human. Overall, the meaning of kelong in data (4) above is that humans must always remember God, who created them, obey His commands and avoiding things He has prohibited.

\section{B. Distortion of Meaning}

Distortion of meaning according to Riffaterre (1984) occurs when a poem contains ambiguity, contradiction, and nonsense. In this study, no-nonsense data was found. Distortion of meaning is only found in the figurative language of ambiguity and contradiction, which consists of irony, litotes, and hyperbole. This is presented in the following data.

a. Ambiguity

Ambiguity is the ability to express more than one interpretation. Ambiguity can be found in the following data:

(5) pappisangkaNa ri katte

Pakabellai ri ati

Na nitunrai

Eroka makgauk salah

The data (5) above shows that there is an ambiguity in the line pappisangkaNa ri katte 'His prohibitions towards you. The ambiguous meaning appears in the word katte which can mean 'you' which is a polite greeting in the Makassar language and can also mean 'we' or first-person plural in the Makassar language. The ambiguous meaning is also shown in the line Pakabellai ri ati which means 'to be kept away from the heart'. The line can mean being kept away from the heart/soul and can also mean being kept away from humans or human life. Overall, the kelong above contains advice to humans that we are obliged to stay away from His prohibition to be always on the right path and to avoid committing sins.

c). Contradiction

The contradiction is a conflict between two opposing or contradictory things. Contradiction distorting meaning in kelong Makassar is reflected by three figures of speech, namely irony, litotes, and paradox. The irony is a figure of speech stating something that is contrary to its actual meaning. Litotes is a figure of speech aimed at expressing something with humility, while paradox is a statement that may seem contradictory but yet can be true or at least makes sense.

Irony can be found in the following data (30). It is aimed at someone who likes to drink alcohol.

(6) Guru tonji punna ballo

Santeri punna palase

Mammaca tonji

Punna nia jukuk langga

An ironic expression is found in the first line guru tonji punna ballok "palm wine is also a teacher". This line contains sarcasm to someone who likes to drink alcoholic beverages (palm wine is considered a teacher) whereas its actual 
meaning is that palm wine is bad for health, prohibited in Islam (the majority of Makassar people are Muslims). In the second line, the term santeri is generally only used in the context of a pesantren or a place to study the Koran. This is very contrary to the first line that pal wine is considered a teacher. Then, sarcasm are also found in the third and fourth lines, mammaca tonji 'only praying' punna nia jukuk langga 'when offered frilled fish'. The third and fourth lines indicate that someone who likes to drink alcohol only prays when they are served grilled fish.

Overall, the meaning of kelong expresses sarcasm to someone who likes to drink alcoholic beverages. The actual meaning to be conveyed is, alcohol is bad for health. Therefore, it is prohibited in Islam. We should live on the right path, do something without expecting anything, and do not do a good deed if only oriented to a moment's pleasure.

Litotes can be seen in the data (35) below,

(7) Tikring kamma anne mae

Ri pakrasangang sunggua

Naniak tonja

Pakrasangang kamaseku

In the data (7), litotes is found on the line ripakrasangan sunggua "in a rich country", and in the line pakrasangang kamaseku "my poor country". Litotes in the first line refers to the humility of a person recognising the wealth of a country. Meanwhile, he also humbles himself to recognise the poverty of his country. In terms of litotes, this kelong means a person's humility to acknowledge the strengths of others and admit that he lives in deprivation.

Hyperbole figure of speech can be found in the following data (8):

(8) baya-baya tea tappuk

Biseang tea taklingge

Palingge sai

Nanicinik barania

In the data (8) above, hyperbole exists in each line, such as baya-baya tea tappuk "the cut resistant rope of a sailboat" which shows the confidence of a person in the middle of the ocean. This is confirmed by the next line biseang tea taklingge 'a boat that cannot swing', which describes the strength of the boat. Logically, biseang is a small boat that has limitations as, in the middle of the ocean, it can be hit by a storm at any time. With high confidence, the sailor shows his bravery through words as found on the Kelong line above. Furthermore, hyperbole is also found on the line palingge sai 'try to swing my boat', which shows the courage of the sailor and of course is only a challenge in the form of words as an ordinary human being who has weaknesses. This is confirmed by the following line, nanicinik barania 'to see who is brave'. In general, the meaning of kelong in the data (33) shows the confidence of the Makassar sailors who are brave and not afraid to challenge the ocean even though they only use simple equipment. This is also a form of responsibility of Makassar men as the backbone of their family.

\section{Creation of Meaning}

According to Riffaterre (1984), the creation of meaning is the granting of meaning to everything that is generally considered to have no meaning, but it has deep meaning in a poem such as the meaning produced by rhyme, semantic equivalence, symmetry, and typography. In this study, the creation of meaning arises from enjambment and typography.

a). Enjambment

Enjambment in poetry (kelong) is defined as the running over of a sentence or phrase from one poetic line to the next, without terminal punctuation. Data containing enjambment is found in the following data (1):

(9) kuminaiko sunggu

kutinjakkiko matekne

manna pucukna

tangkenna matene ngaseng

The third line shows the creation of meaning, manna pucukna 'even the shoots', and the fourth line, tangkenna matetekne ngaseng 'the twigs are all happy'. This is indicated by the second word of the third line, pucukna, and the first word of the fourth line, tangkenna. These two words are a series of the same object that cannot be separated. The meaning created is that although the shoots and stalks are two different things, both reflect an inseparable combination. The actual meaning is that happiness in life takes place due to togetherness among humans who support each other and pray for one another.

b). Typography

Typography in poetry is the arrangement of lines, verses, sentences, phrases, words, and sounds to produce a physical form that can support the content, taste, and context. Typography is an important thing that distinguishes poetry from prose and drama. All data in this study represent typography. The form of kelong has its characteristics like in the following data (2),

(10) Asmbayangko nutambung

Pakajai amalaknu

Nanu jarreki

Kananna anrong gurunnu

Asmbayangko nutambung

Pakajai amalaknu 
Nanu jarreki

Kananna anrong gurunnu
(8)

Data (2) shows the characteristics of lines in kelong; a unit to support meaning. Unity of sound in each line is a syntactic unit in the form of words or groups of words with $2 / 2 / 1 / 2$ pattern, and the pattern of syllable on each line is $8 / 8 / 5 / 8$.

\section{DISCUSSION}

Indirection of Meaning in Poetry

An essential characteristic of poetry according to Michael Riffaterre (1984) is that poetry expresses concepts and objects indirectly. Simply put, poetry says one thing for another. This is what distinguishes poetry from the language in general. Poetry has a particular way to convey its meaning (Faruk, 2012:141). Poetic language is semiotic while everyday language is mimetic. Poetry's indirection of meaning takes place due to the displacement of meaning, distortion of meaning, and creation of meaning (Riffaterre, 1984).

1) Displacement of Meaning

Displacement of meaning occurs when a sign changes from one meaning to another when a word represents another word. In this study, the displacement of meaning is found in metaphor, metonymy, personification and pars pro toto. The four types of figurative language are comparative that can lead to the displacement of meaning, but the meaning that emerges is the one that is close to the meaning referred to. This is presented in data (1),(2),(3), and (4).

2) Distortion of Meaning

Distortion of meaning occurs because of ambiguity, contradiction, and nonsense. Ambiguity can occur in words, phrases, sentences, or discourses due to the emergence of different interpretations according to context. The contradiction arises because of the use of irony, paradox, and antithesis. Nonsense refers to words that have no meaning (not in the dictionary) but have "magical" meanings according to the context (Salam, 2009, p.4). In this study, no data was found to distort meaning due to nonsense. Distortion of meaning is caused by ambiguity and contradiction which consists of irony, litotes, and hyperbole. This is reflected by data (5), (6),(7), and (8).

3) Creation of Meaning

In this study, the creation of meaning occurs because of text space organization including enjambment and typography. Enjambment is the continuation of a sentence without a pause beyond the end of a line, couplet, or stanza. It gives rise to the intensity of meaning or lyrical meaning. Typography in a text does not mean anything, but in poetry, it has meaning. This can be found in data (9) and (10), each of which comes from enjambment and typography.

\section{CONCLUSION}

Based on the results of data analysis, it can be concluded that three things cause the indirection of meaning: (1) displacement of meaning, found in metaphor, metonymy, personification, and pars pro toto which are comparative figures of speech. The words contained in the lines can bring out hidden and different meanings behind the textual meaning of kelong, (2) distortion of meaning in kelong Makassar, shown in ambiguities and contradictions consisting of irony, litotes, and hyperbole. The words in kelong lines can show ambiguity that gives rise to distortion of meaning. The irony, litotes, and hyperbole give rise to sarcastic meanings in contrast to textual meaning. (3) The creation of meaning found in this study occurs due to enjambment and typography.

\section{REFERENCES}

[1] Ahmed, Umar. (2018). Metaphor in the Construction of Gender in Media Discourse: Analysis of Metaphors Used to Describe Women in Nigerian Newspaper. International of Journal of Gender and Women's. Edisi Juni, 6(1).

[2] Alfayanti, Lerry dkk. (2017). Symbolic Meanings of Among Tebal Ritual in Novel Genduk By Sundari Mardjuki, Jurnal Ilmiah Ilmu-Ilmu Humaniora Humanus, 16(2).

[3] Amir, adriyetty. (2013). Sastra Lisan Indonesia. Jakarta: Dian Rakyat.

[4] Aytekin, Cemile Arzu. (2014). On the Tracks of Literary Structure in Literary Work (a Sumerian Poem), Procedia - Social and Behavioral Sciences. Edisi Desember. 158, p.43-50.

[5] A Basang, Djirong. (1975). Taman Sastra Makassar. Ujung Pandang: CV Alam.

[6] B.F. Matthes. (1860). Makassarche Chrestomatie. Amsterdam: C.Aspin \& Zoon

[7] Boezar, Razi, dkk. (2016). (Semiotic Analysis of Place and Time in Poems of Badr Shakir al-Sayyab), Journal of History Culture and Art Research, Edisi Desember. 5(4).

[8] Globe, Alexander. (1974). The Literary Structure and Unity of the Song of Deborah. Journal of Biblical Literature. Edisi Desember, 93(4).

[9] Hakim, Chaeruddin. (2006). Kitab Kelong. Gowa: Glora Pustaka Indonesia.

[10] Pusat Pembinaan dan Pengembangan Bahasa.

[11] Miles, Matthew B. dan A. (1992). Michael Huberman. Tanpa Tahun, Analisis Data Kualitatif: buku sumber tentang Metodemetode baru. Terjemahan Oleh Tjetjep Rohendi Rohidi, Jakarta: Penerbit Universitas Indonesia (UI-Press).

[12] Nasaruddin, dkk. (2011). Kearifan Lokal di Tengah Modernisasi. Jakarta: Pusat Penelitian dan Pengembangan Kebudayaan Badan Pengembangan Sumber Daya Kebudayaan dan Parawisata Kementrian Kebudayaan dan Parawisata Repeblik Indonesia. 
[13] Pashaki, Ahmad Muhammadi Nejad. (2016). (Semiotics in Haroun Hashem Rashid Lyrics Relying on The Theory of), Jurnal Internasional Bahasa Inggris Linguistik, Edisi Desember, 6(7).

[14] Pradopo, Rachmat Djoko. (2012). Pengkajian Puisi. Yokyakarta: Gadjah Mada University Press.

[15] Riffaterre, Michael. (1984). Semiotics Of Poetry. Bloomington and London: Indiana University Press.

[16] Sadehi, Kamelia talebian. (2012). Beloved and Julia Kristove's The Semiotic and The Symbolic. Teori dan Praktek dalam Ilmu Bahasa, Edisi Juli, 2(7).

[17] Sadehi, Kamelia Talebian \& Omar Mohammad Abdullah. (2015). Semiotic and Symbolic Aspects of Language in John Donne's Selected Poems. Jurnal Ilmu Sosial Mediterania, Edisi Agustus, 6(4).

[18] Salam. (2009). Pembelajaran Menulis Puisi Dengan Metode Michael Riffaterre.

[19] Setiawan, Eko Putra. (2017). Pusat Kajian Humaniora: Humanus. Edisi Nopember, XVI(2). The Meaning And Teaching of "Budi Pekerti" Iin The Poetry of Kekean By F. Aziz Manna: Semiotic Studies of Riffateer

[20] Sibarani, Robert. (2012). Kearifan Lokal: Hakikat, Peran, dan Metode Tradissi Lisan. Jakarta: Asosiasi Tradisi Lisan

[21] Suardiman, Sitti Partini. (2017). (Developing Thematic Integrated Teaching Materials Based on Local Wisdom to Improve Care and Responssibility). Jurnal Internasional Pendidikan Karakter. Edisi April (2017), TH. VII, No. 1.

[22] Yasa, I Nyoman. (2012). Teori Sastra dan Penerapannya. Bandung: Karya Putra Darwati.

Hajrah Pallangga Gowa was born on October 25, 1972. The first child of the couple Nurdin and Fatimah. Started studying at an elementary school in one of the elementary schools in the District of Jeneponto. Although several times moved the school can eventually graduated from the primary school in the year 1985 in presidential instruction elementary school Pallangga. Then continued his education at the middle school level, First in junior high Country Pallangga and graduated in 1988. Continuing education to high school level in SMA Negeri 159 Sunggumunasa, Gowa and graduated in 1991. Later in the same year continuing education level Strata one (S1) at the Faculty of literature, Department of literature of Indonesia, Hasanuddin University, completed in 1996. In 1999 Continued graduate studies at the State University of Makassar Strata level two (S2) on the Indonesian Language education courses, and completed in 2001. Currently he is continuing education graduate level three Strata (S3) State University in Makassar on the Indonesian Language education courses. The author is one of the educational personnel at the instance of the State University of Makassar and served on the Faculty of language and literature.

Muhammad Rafi Tang, was born in Soppeng in 1960. He graduated his doctoral program in Universitas Negeri Malang, Department of Bahasa Indonesia. He is professor of Language Education and Literature of Faculty of Language Education and Literature in Universitas Negeri Makassar. His scientific paper is La Dado Lele Angkuru-e, Sastra Bugis Klasik (philology study). Lecturer in subject of philology and introduction to Literature, classic literature. His book is Pengantar Kajian Kesusastraan

Suradi Tahmir, born in Bone, dated April 13, 1964. Education is a starting elementary level until the HIGH SCHOOL was completed in the Bone. The year 1988 studies undergraduate (S-1) in education of mathematics at IKIP Ujung Pandang. Year 19891990 follow education pre-existent S2 ITB. The year 1992 completed a master's degree (S-2) on Math courses with degree of M.S. Year 2005 completed the doctoral program in education (S-3) in the field of mathematics education in the UNESA Surabaya. Since the year 1989 became a lecturer on Mathematics Education Study Program of ENGINEERING IKIP Ujung Pandang (UNM). The experience of the Office of the Secretary of 1996-2000 year majoring in mathematics education FPMIPA, year 2005-2006 Program Chair of mathematical Education Studies, year 2006-2010 Program Chair mathematics education Study Program of S-2 PPs UNM, Assistant Director of the 2010-2016 year I (Academic) PPS UNM and Publication Cooperation Coordinator PPs UNM. Year 2000 Associate Professor on a clump of courses of algebra and in 2007 the post of full Professor (professor) in the field of mathematics education. Some training has ever followed include: internship research mathematics education in ITB Bandung, a research workshop on mathematics at ITB and practical management of laboratory SCIENCES education in the ICU. Several books written include: algebraic structures. In addition, writes scientific papers and articles from a variety of research that was published in several scientific journals, both national as well as international article. In addition, also active as participants and speakers at scientific meetings, both national and international levels.

Kembong Daeng born in bontolebang, Takalar Regency on 31 December 1964. He is one of the educational personnel on duty in Makassar State University Faculty of letters. The current Chairman of the Regional Language education courses. He is also one of the authors of literary and cultural observers as well as Makassar of South Sulawesi, Makassar culture in particular. Educational background, educated Strata one (S1) in IKIP Ujung Pandang in 1984 and completed in 1988 on the Education of language and literature. Educated at the level of two Strata (S2) at Hasanuddin University in 1993 and was completed in 1996 on the linguistic Course. Then educated Strata of three (S3) in 2009 year Makssar State University and completed in 2013 on the Education of the science of language. 